\title{
Spatio-temporal measurements and analysis of snow depth in a rock face
}

\author{
V. Wirz ${ }^{1,2}$, M. Schirmer ${ }^{1}$, S. Gruber ${ }^{2}$, and M. Lehning ${ }^{1,3}$ \\ ${ }^{1}$ WSL Institute for Snow and Avalanche Research SLF, Davos, Switzerland \\ ${ }^{2}$ Department of Geography, University of Zurich, Switzerland \\ ${ }^{3}$ School of Architecture, Civil and Environmental Engineering, Ecole Polytechnique \\ Fédérale de Lausanne, Lausanne, Switzerland
}

Received: 13 April 2011 - Published in The Cryosphere Discuss.: 6 May 2011

Revised: 11 October 2011 - Accepted: 13 October 2011 - Published: 21 October 2011

\begin{abstract}
Snow in rock faces plays a key role in the alpine environment for permafrost distribution, snow water storage or runoff in spring. However, a detailed assessment of snow depths in steep rock walls has never been attempted. To understand snow distribution in rock faces a high-resolution terrestrial laser scanner (TLS), including a digital camera, was used to obtain interpolated snow depth (HS) data with a grid resolution of one metre. The mean HS, the snow covered area and their evolution in the rock face were compared to a neighbouring smoother catchment and a flat field station at similar elevation. Further we analyzed the patterns of HS distribution in the rock face after different weather periods and investigated the main factors contributing to those distributions.

In a first step we could show that with TLS reliable information on surface data of a steep rocky surface can be obtained. In comparison to the flatter sites in the vicinity, mean HS in the rock face was lower during the entire winter, but trends of snow depth changes were similar. We observed repeating accumulation and ablation patterns in the rock face, while maximum snow depth loss always occurred at those places with maximum snow depth gain. Further analysis of the main factors contributing to the snow depth distribution in the rock face revealed terrain-wind-interaction processes to be dominant. Processes related to slope angle seem to play a role, but no simple relationship between slope angle and snow depth was found.

Further analyses should involve measurements in rock faces with other characteristics and higher temporal resolutions to be able to distinguish individual processes better. Additionally, the relation of spatial and temporal distribution of snow depth to terrain - wind interactions should be tested.
\end{abstract}

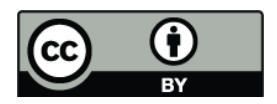

Correspondence to: V. Wirz (vanessa.wirz@geo.uzh.ch)

\section{Introduction}

Knowledge on spatial and temporal variability of snow depths in alpine terrain is of high importance because snow plays an important role in many alpine environmental aspects, e.g. water management, snow avalanche formation or permafrost occurrence. The snow distribution in rock faces influences the existence of permafrost (Haeberli, 1996; Keller and Gubler, 1993; Lütschg et al., 2008; Hasler et al., 2011) and contributes to the runoff in spring. As rock faces are widespread in alpine environments (e.g. Gruber and Haeberli, 2007), knowledge about the distribution of snow depth in them is important. However, such studies are rare due to the limitations of traditional measurement methods in combination with the inaccessibility and the existence of alpine hazards. By contrast, snow depth distribution in less steep alpine terrain has been studied for many years (e.g. Föhn and Meister, 1983; Cline et al., 1998; Liston and Sturm, 1998; Gauer, 2001; Deems et al., 2006; Doorschot et al., 2001; Mott and Lehning, 2010) and recent ground temperature trend analyses underline the importance of spatial and temporal snow depth distribution (Zenklusen et al., 2010).

The distribution of snow depth in mountain regions is mainly influenced by the amount of precipitation, solar radiation, air temperature, wind conditions, topography and other processes related to their interactions. On a smaller scale, for example within alpine watersheds, the spatial variability of snow depth is mainly determined by terrain-wind interactions (e.g. Föhn and Meister, 1983; Elder et al., 1991; Luce et al., 1998; Gauer, 2001; Winstral et al., 2002; Raderschall et al., 2008; Lehning et al., 2008) and therefore a lot of effort has been carried out to link snow depths to meteorological (especially wind) and topographic factors (e.g. Blöschl and Kirnbauer, 1992; Anderton et al., 2002; Winstral et al., 2002; Trujillo et al., 2007; Grünewald et al., 2010; Mott et al., 2010).

Published by Copernicus Publications on behalf of the European Geosciences Union. 
In steep terrain, such as rock walls, it is to be expected that the spatio-temporal variability of snow depth is not only caused by wind transport but also influenced by processes related to slope angle and slope aspect such as solar radiation and avalanching (including avalanches, sloughs and spindrifts). As knowledge about the snow depth distribution in rock faces is scarce, many hypotheses have been formulated but could so far not be verified properly. Due to the high influence of gravity in steep terrain, different authors assumed that snow cannot accumulate permanently (Winstral et al., 2002; Blöschl and Kirnbauer, 1992; Schmid and Sardemann, 2003). The latter presume that small sloughs starting from slopes steeper than $55^{\circ}$ are frequent while larger avalanches are rare. Another frequent assumption is that with increasing slope angle the snow depth and snow covered area decrease (e.g. Anderton et al., 2002; Machguth, 2006). This assumption has been confirmed by observations in alpine basins at a resolution of $25 \mathrm{~m}$ (Blöschl and Kirnbauer, 1992).

LIDAR altimetry makes it possible to measure area-wide the snow depths with high accuracy, even in inaccessible areas. Airborne laser scanning (ALS) was successfully used in previous studies to determine snow depth distribution in alpine terrain (e.g. Deems et al., 2006; Hopkinson et al., 2004). In the last few years the technique of terrestrial laser scanning (TLS) has increased the possibilities to measure snow surfaces with higher spatial and temporal resolution (Bauer and Paar, 2005; Jörg et al., 2006; Prokop, 2008; Schaffhauser et al., 2008; Grünewald et al., 2010). TLS measurements have already been used to obtain precise digital elevation models of rock faces (Bauer et al., 2005; Alba et al., 2005). Until present, TLS has never been applied to investigate the variability of snow depths on rock faces.

In this study we examine TLS measurements to receive snow depth data with a resolution of one metre in a rock face in the eastern Swiss Alps. The aim is to obtain information on (a) the amount of snow depth in the rock face and its temporal evolution compared to flatter sites at similar elevation and in the vicinity, (b) the spatial-temporal variability of snow depths and (c) possible inferences for processes causing this distribution. A strong focus will be on studying probable key factors influencing the snow depth distribution and to investigate how far snow depth distribution is linked to frequently used terrain parameters such as slope, curvature and roughness. Regarding the terrain parameters we assume that in a rock face more snow can accumulate in the steep, rough areas than in the steep, smooth ones and that curvature influences both avalanching and wind drift. Finally, frequently made hypotheses, such as the one that with increasing steepness snow depth decreases and that on slopes steeper than a specific threshold snow cannot accumulate, were tested for the rock face on a small scale.

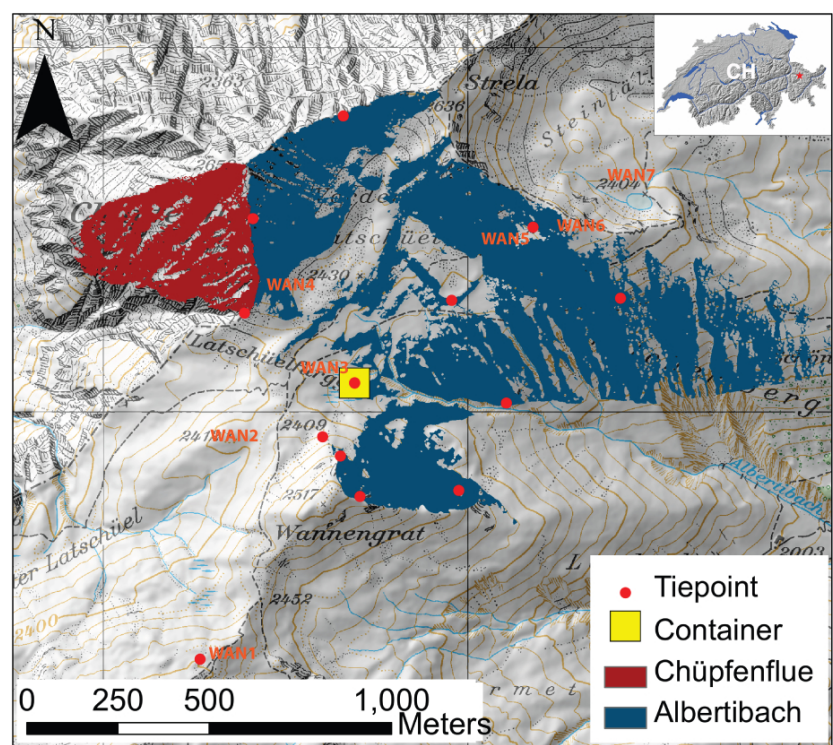

Fig. 1. Overview of the study site Wannengrat (region of Davos, Switzerland). Snow depths were measured with a terrestrial laser scanner (TLS) in the south-west face of the Chüpfenflue and in the catchment of Albertibach. The used equipment was stored in a container. To convert the TLS point-cloud into a Swiss coordinate system several fixed-installed reflectors (tie points) were used. Seven automatic weather stations (WAN1 to WAN7) deliver important additional information (e.g. temperature, wind-direction). For measurements in the Chüpfenflue the TLS was positioned next to the weather station WAN2.

\section{Data and methods}

\subsection{Study site}

The main study site Chüpfenflue is a southwest oriented slope in the region of Davos, Eastern Swiss Alps (Fig. 1). The rock face elevation ranges from 2200 to $2658 \mathrm{~m}$ a.s.l. The mean slope angle is $42^{\circ}$ varying from horizontal to nearly vertical (max. $86^{\circ}$, calculated on a grid of $1 \mathrm{~m}$ resolution, Fig. 2). The base area (horizontal projected area) of the rock face is about $0.16 \mathrm{~km}^{2}$, of which approximately $60 \%$ were covered by the TLS measurements. Surrounding the Chüpfenflue, seven automatic weather stations measure wind direction and velocity, air temperature, relative humidity and solar radiation, and several fixed reference points with reflectors are available for referencing the TLS measurements (Fig. 1).

Two sites at similar elevations were used to compare the snow depth in the rock face to more gentle terrain: the nearby Albertibach catchment and the Versuchsfeld Weissfluhjoch. The neighbouring Albertibach is generally smoother, less steep (mean slope of $30^{\circ}$, Fig. 2) and includes diverse slope aspects (data published in Grünewald et al., 2010 and Schirmer et al., 2011). It has a horizontal area of $1.3 \mathrm{~km}^{2}$ of which $46 \%$ were covered by TLS. The flat field Versuchsfeld 


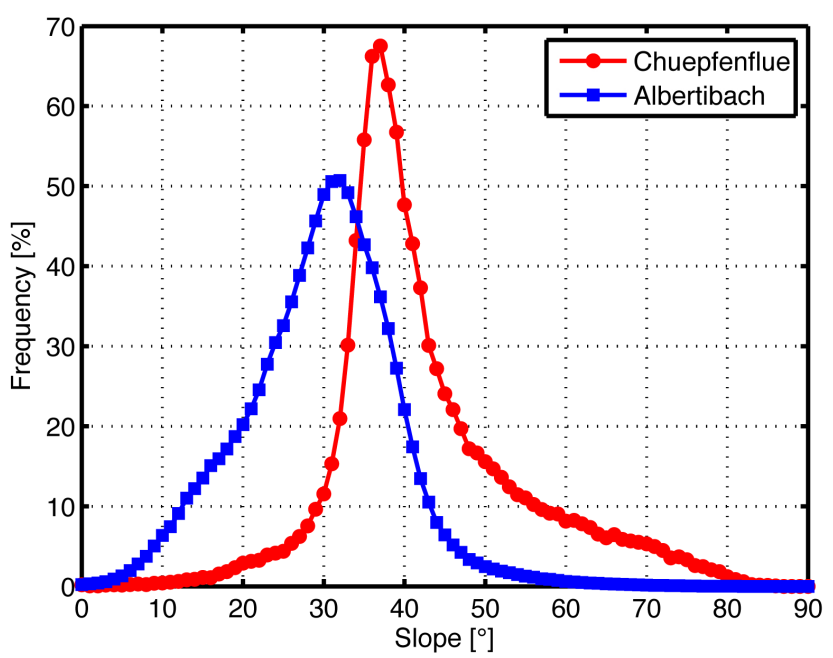

Fig. 2. Histogram with the relative frequency (calculated for classes with a step width of $1^{\circ}$ slope) of the slope.

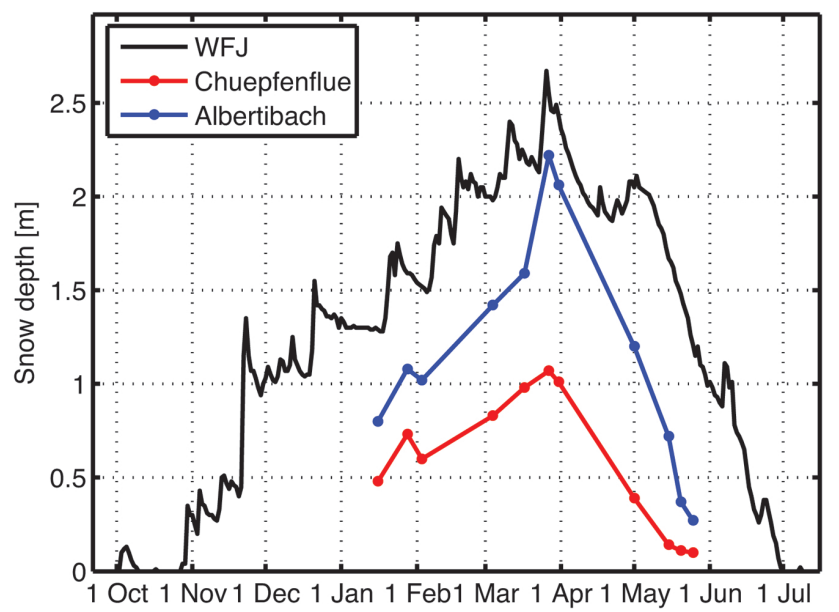

Fig. 3. Course of the snow depth measured daily at the Versuchsfeld Weissfluhjoch (WFJ) and the mean snow depth $\left(\mathrm{HS}_{\text {tot }}\right.$, calculated for the entire base area) of the rock face Chüpfenflue and the Albertibach catchment from winter 2008/2009.

Weissfluhjoch (WFJ, $2540 \mathrm{~m}$ a.s.l) has one of the longest records of snow depth observations worldwide and has been subject to numerous investigations (e.g. Stoessel et al., 2010). For our purpose, snow depth was measured daily at one point (SLF, 2009, Fig. 3).

\subsection{Weather conditions}

The seasonal development of snow depth measured at WFJ during winter 2008/2009 was similar to the long-term mean (1934 to 2008) although snow depth was generally higher than average (SLF, 2009). The accumulation season at WFJ started at the end of October 2008. Throughout the accumulation season, snowfalls were predominantly observed in
Table 1. Technical features of the used long range laser measuring systems (LPM-321; Riegl, 2005).

\begin{tabular}{ll}
\hline Parameter & Value \\
\hline Principle & Time-of-flight \\
Wavelength & $905 \mathrm{~nm}$ \\
Pulsrate & $20000 \mathrm{~Hz}$ \\
Beam spread angle & $0.8 \mathrm{mrad}$ \\
Max. range, with reflectance $<80 \%$ and $1000 \mathrm{~Hz}$ & $1500 \mathrm{~m}$ \\
Used resolution for finescans & $0.36^{\circ}$ \\
Accuracy & $25 \mathrm{~mm} \pm 20 \mathrm{ppm}$ \\
\hline
\end{tabular}

combination with strong northwest winds in the Albertibach catchment and at WFJ. At the end of January, the stations measured snowfall in combination with weak winds, after the collapse of a Föhn event (strong, dry southerly winds). Another Föhn event was responsible for the reduction of snow depth in the region of Davos in the beginning of February. The accumulation season ended at the end of March (26 March, Fig. 3) and was followed by a period of strong ablation. Towards the end of April, the ablation process was interrupted by a period with little snowfall and colder temperatures. In May, ablation was high due to warm temperatures. On 25 May (last measurement), the rock face was nearly snow free, while the Albertibach catchment still had over $30 \%$ snow cover. The Albertibach catchment became snow free at the end of June (Egli et al., 2011), the Versuchsfeld WFJ at the beginning of July (Fig. 3, SLF, 2009).

\subsection{Measurement methods}

The TLS used in this study (Riegl, LPM-321, Table 1) measures distances with a near-infrared signal with a wavelength of $905 \mathrm{~nm}$, ensuring favourable reflectance of the snow (Painter and Dozier, 2004) and little penetration of the laser signal (Prokop et al., 2008). The density of the resulting point cloud depends on the distance to the object, the inclination angle and the resolution used. The distance, inclination angle and point divergence determine the size of each laser footprint. With distances to the surface ranging from 350 to $700 \mathrm{~m}$ and a resolution of $0.36^{\circ}$, the average point density was 6.12 points per square meter. Circular footprints had diameters of $0.14-0.28 \mathrm{~m}$, but were usually enlarged to ellipses where incidence angles were small. The actual error estimation is discussed in the Sect. 2.5.

The TLS was positioned next to the weather station WAN2 (Fig. 1), installed on a stable tripod. To minimize errors caused by a slight settling or tilting of the tripod, the duration of one scan was restricted to one hour and before each scan the position of the TLS was re-determined. Especially at the foot of the face and behind large ridges, gaps in the measured surface resulted from measuring shadows (blind areas, Fig. 1). Additionally, a digital camera (Canon EOS 
350D) installed on the TLS, was used to take high-resolution photos during measurements that were ortho-rectified during processing.

The dataset for the main site consists of 14 TLS measurements with snow during the winter 2008/2009 (January-May 2009), one measurement after the first snowfall of the winter 2009/2010 (21 October) and one scan without snow, serving as the digital elevation model (DEM, Table 3). Additionally, two helicopter-based ALS (Vallet et al., 2005; Skaloud et al., 2006) data sets covering the entire area in 2009 were used: one from 9 April close to peak snow depth in the area and one from 19 September in snow free conditions. The time lag between the TLS measurements of Chüpfenflue and Albertibach was less than two days. In April, no measurements were made in the Albertibach catchment. An overview of the periods used for comparing Chüpfenflue, Albertibach and WFJ is given in Table 2.

\subsection{Processing}

TLS data were processed with the software RiProfile (Riegl, version, 1.4.3). Measurements were corrected for atmospheric and geometric influences and filtered to achieve a more balanced point density (octree-filter; Riegl, 2005). The measured point cloud was transformed into the Swiss coordinate system CH1903 using seven permanently installed reflectors with known coordinates. Based on the point-cloud obtained with the TLS, we used the standard Delaunay triangulation (Delaunay, 1934) within ArcGIS to obtain a digital surface model (DSM). The maximal edge length of the triangles was limited to $5 \mathrm{~m}$ to prevent interpolation in obvious measuring shadows but to ensure that areas of low point density are still triangulated. The resulting triangulated irregular networks (TINs) were converted by a linear interpolation into DSMs with a grid resolution of one meter. The optimal cell size for the DSM grids was estimated, by comparing the volume of snow depth change of three accumulation periods calculated with different cell sizes (between $0.5 \mathrm{~m}$ and $10 \mathrm{~m}$ ) to the reference volume (calculated based on the TIN). The results were similar for all cell sizes and errors were always smaller than $2 \%$ of the TIN volume. The resolution of one meter offered a good compromise between resolution, data storage requirements and the retention of original data points. Snow depth changes over time are calculated by subtracting DSM grid values of differing measurement dates; snow depth by subtracting DSM grid values from the DEM. In this study we use snow depth (HS) referring to the vertical height (perpendicular to the earth centre) as it is used to estimate the snow water equivalent (Fierz et al., 2009).

Snow covered area (SCA) is important to understand the distribution of HS, however, using TLS only, it cannot be examined precisely as the snow cover in the rock face is often thin and lies within the uncertainty of the HS data generated by subtraction (see next Section). To overcome this, a binary raster mask of SCA for each measurement day was generated manually using a threshold for one of the colour orthophoto $3 * 8$ bit RGB channels. During the accumulation season, a blue value higher than 140 and during the ablation season red values between 160 and 230 were used as thresholds for snow.

To estimate the HS changes only those cells were included which were snow covered at the beginning and at the end of the period analyzed. This restriction allows excluding cells, which get snow free during the observation period and therefore facilitates the determination of reliable ablation rates (the term ablation is used here to summarize all processes causing negative HS changes). The rare case is excluded in which many pixels may show a small ablation rate for a given time period between TLS measurements, caused by the fact that the pixel was already close to complete melt at the start of the period. Mean HS is therefore also given with respect to the snow-covered base area. The only exception to this is the comparison with Albertibach and WFJ where mean HS is calculated for the entire base area $\left(\mathrm{HS}_{\text {tot }}\right)$ the aim was to get an idea about the total amount of HS with respect to the area within a study site.

Based on the summer DEM, slope angle, curvature and surface roughness (VRM; Sappington et al., 2007) were calculated within ArcGIS. As this strongly depends on cell size, we derived terrain parameters at diverse resolutions $(1 \mathrm{~m}$, $5 \mathrm{~m}, 10 \mathrm{~m}$ and $25 \mathrm{~m}$ ) in order to analyze the effects of small vs. bigger terrain features.

\subsection{Data quality analysis}

Prokop et al. (2008) and Grünewald et al. (2010) quantified the error of snow depth measurements achieved with terrestrial laser scanning systems in alpine terrain and compared it to other established methods such as tachymeter or manual snow probing. Prokop et al. (2008) showed that at distances up to $300 \mathrm{~m}$ the mean difference $(\mu)$ between the methods was $4.5 \mathrm{~cm}$ with a standard deviation $(\sigma)$ of approximately $2 \mathrm{~cm}$. The measurements carried out by Grünewald et al. (2010) and by Kenner et al. (2011), using the same TLS as in this study yielded similar results (up to $250 \mathrm{~m}$ : $\mu=4 \mathrm{~cm}$ and $\sigma=5 \mathrm{~cm}$ ). These results cannot be transferred directly to the rough and steep surface examined here and tachymeter-based reference measurements without a reflector were impossible due to the large distance between TLS and rock face. We tested our measurements for repeatability (same setup, unchanged object) on four days and for reproducibility (changed setup, unchanged object) once for the snow-covered surface and on four days for the snow-free surface. Additionally, TLS and ALS measurements of the snow free rock face were compared to analyze errors in blind areas of the TLS and to compare both methods.

All repeatability tests showed similar results and we present the results of 17 March only. A mean error of $8.7 \mathrm{~cm}$ (mean of the absolute differences, $\left(\mu_{\mathrm{AE}}\right)$ together with a standard deviation of $20.3 \mathrm{~cm}$ was observed. The offset $(\mu)$ 
Table 2. Observation periods (given by two following TLS measurements), snow depth change (dHS) at the Versuchsfeld Weissfluhjoch (WFJ), the Chüpfenflue (Chüpfen.) and the Albertibach catchment (Albertib.) and their variability (CV). The periods refer to the periods used in Table 3.

\begin{tabular}{ccrrrrr}
\hline Date & Period & $\begin{array}{r}\text { WFJ } \\
\text { dHS [m] }\end{array}$ & $\begin{array}{r}\text { Chüpfen. } \\
\text { dHS [m] }\end{array}$ & CV & $\begin{array}{r}\text { Albertib. } \\
\text { dHS [m] }\end{array}$ & CV \\
\hline 16 Jan-28 Jan 2009 & 1 & 0.32 & 0.28 & 0.62 & 0.25 & 0.78 \\
28 Jan-3 Feb 2009 & 2 & -0.08 & -0.13 & -0.93 & -0.10 & -1.02 \\
3 Feb-4 Mar 2009 & 3 & 0.46 & 0.32 & 1.22 & 0.41 & 1.32 \\
4 Mar-17 Mar 2009 & 4 & 0.22 & 0.16 & 1.45 & 0.24 & 1.08 \\
17 Mar-27 Mar 2009 & 5 & 0.31 & 0.13 & 1.78 & 0.41 & 0.74 \\
27 Mar-31 Mar 2009 & 6 & -0.13 & -0.05 & -3.43 & -0.10 & -1.62 \\
31 Mar-1 May 2009 & $7 / 8 / 9$ & -0.37 & -0.72 & -0.75 & -0.81 & -0.50 \\
1 May-15 May 2009 & $10 / 11$ & -0.38 & -0.32 & -1.44 & -0.52 & -0.31 \\
16 May-20 May 2009 & 12 & -0.21 & -0.35 & -0.61 & -0.33 & -0.33 \\
21 May-25 May 2009 & 13 & -0.31 & -0.63 & -0.30 & -0.45 & -0.29 \\
\hline
\end{tabular}

Table 3. Observation periods in the southwest face of the Chüpfenflue: name of the period, date, mean snow depth change of the snow covered cells (dHS, in m), snow depth at the end of the period ( $\mathrm{HS}_{\text {end }}$, in $\mathrm{m}$ ), coefficient of variation of the snow depth change (CV dHS) and coefficient of variation of $\mathrm{HS}_{\text {end }}\left(\mathrm{CV} \mathrm{HS}_{\text {end }}\right)$ and the main weather situation.

\begin{tabular}{lcrrrrc}
\hline Periods & Date & dHS [m] & $\mathrm{HS}_{\text {end }}[\mathrm{m}]$ & CV dHS & CV HS end & Weather situation \\
\hline DGM & 23 Aug 2008 & & & & & \\
Period 1 & 16 Feb-28 Feb 2009 & 0.28 & 0.80 & 0.62 & 0.68 & Snowfall with weak wind \\
Period 2 & 28 Jan-3 Feb 2009 & -0.13 & 0.67 & -0.93 & 0.79 & Föhn event \\
Period 3 & 3 Feb-4 Mar 2009 & 0.32 & 0.96 & 1.22 & 0.81 & Snowfall with NW-wind \\
Period 4 & 4 Mar-17 Mar 2009 & 0.16 & 1.14 & 1.45 & 0.80 & Snowfall with NW-wind \\
Period 5 & 17 Mar-27 Mar 2009 & 0.13 & 1.28 & 1.78 & 0.84 & Snowfall with NW-wind \\
Period 6 & 27 Mar-31 Mar 2009 & -0.05 & 1.30 & -3.43 & 0.90 & HS reduction \\
Period 7 & 31 Mar-15 Apr 2009 & -0.89 & 0.94 & -0.34 & 1.01 & HS reduction \\
Period 8 & 15 Apr-24 Apr 2009 & -0.19 & 0.84 & -0.81 & 1.51 & HS reduction \\
Period 9 & 24 Apr-1 May 2009 & 0.06 & 0.53 & 2.42 & 1.11 & Snowfall \& HS reduction \\
Period 10 & 1 May-7 May 2009 & -0.13 & 0.80 & -1.26 & 1.36 & HS reduction \\
Period 11 & 7 May-15 May 2009 & -0.56 & 0.59 & -0.56 & & HS reduction \\
Period 12 & 15 May-20 May 2009 & -0.35 & 0.77 & -0.61 & 1.08 & HS reduction \\
Period 13 & 20 May-25 May 2009 & -0.63 & 0.84 & -0.3 & 0.88 & HS reduction \\
Period 0 & Oct 2009 & 0.18 & 0.18 & 1.77 & 0.77 & Snowfall with NW-wind \\
\hline
\end{tabular}

was negligible $(\mu=-2.9 \mathrm{~cm})$. The results of the reproducibility were similar but with slightly larger deviations $(\mu \mathrm{AE}=13 \mathrm{~cm}, \mu=-18.5 \mathrm{~cm}$ and $\sigma=38 \mathrm{~cm})$. In most cases, the main differences occurred in the rough parts of the rock face. In those rough and steep areas the main deviations between DEMs derived from TLS and ALS occurred. The comparison with ALS data confirmed that within blind areas of the TLS it was not possible to interpolate appropriately. The absolute differences between the two DEMs excluding blind areas were on average $\mu_{\mathrm{AE}}=48.2 \mathrm{~cm}, \mu=38.5 \mathrm{~cm}$ and $\sigma=81 \mathrm{~cm}$ with elevations based on TLS generally being higher. The offset between both data sets probably resulted from wrong calibration of the reference points. We therefore did not calculate snow depths derived from different LIDARmethods.

\subsection{Explorative data analysis}

In an attempt to describe the amount of snow and its temporal evolution in the rock face comparatively, we compare the mean $\mathrm{HS}_{\text {tot }}$, the mean HS changes as well as SCA between the rock face and more gentle terrain. The dataset was analyzed visually and with descriptive statistics (histogram, mean $\mu$ and standard deviation $\sigma$ ). To describe the variability of HS, the coefficient of variation $(\mathrm{CV}=\sigma / \mu)$ was used. The simple linear regression coefficient $(R)$ of Pearson for two univariate variables was applied to quantify the similarity 
between different spatial distributions of HS. The KruskalWallis-Test is used to study which factors are relevant for HS patterns. We tested if variability of HS can be explained by a simple terrain parameter again using Pearson's coefficient of determination $(R)$ for two univariate variables. We further analyzed if a linear relation exists between simple terrain parameters to HS patterns of different periods. The most common parameters used in previous studies include elevation, slope aspect, slope and curvature (e.g. Golding, 1974; Elder, 1998). As only small ranges of slope aspect (SSE to W) and elevation (2100 to $2700 \mathrm{~m}$ a.s.l.) were measured in the rock face, it was not possible to study the influence of the frequently used parameters slope aspect and elevation on the snow distribution. We therefore analyzed the correlations between slope, curvature and surface roughness and snow depth distribution. The parameter surface roughness was included, because in a rock face more snow may accumulate in steep rough parts than in steep smooth terrain. The used terrain parameters were all calculated within ArcGIS. To describe the surface roughness we used the vector-based parameter VRM (Vector Roughness Measurement) described by Sappington (2007).

\section{Results}

\subsection{Comparison with more gentle terrain}

The evolution of mean $\mathrm{HS}_{\text {tot }}$ at Chüpfenflue, Albertibach and Versuchsfeld Weissfluhjoch (WFJ) were similar (Fig. 3): At all three sites the peak of winter accumulation was reached at the end of March and from January to the end of the accumulation season, the mean $\mathrm{HS}_{\text {tot }}$ increased by about $50 \%$. Furthermore, at all three locations a reduction of $\mathrm{HS}_{\text {tot }}$ occurred at the beginning of February due to a Föhn event. A period with strong ablation at the beginning of April followed the peak of winter accumulation. From the end of March to the end of May the $\mathrm{HS}_{\text {tot }}$ decreased. In May, when air temperatures measured in the study area stayed above zero degrees nearly daily, the reduction was particularly strong.

Mean $\mathrm{HS}_{\text {tot }}$ at Chüpfenflue was constantly smaller, with a maximum difference of $1.5 \mathrm{~m}$ to WFJ on 1 May and $1.1 \mathrm{~m}$ to the Albertibach catchment on 27 March (Fig. 3). At the end of the accumulation season, mean $\mathrm{HS}_{\text {tot }}$ at Chüpfenflue was $1.1 \mathrm{~m}, 2.2 \mathrm{~m}$ at Albertibach and $2.4 \mathrm{~m}$ at the Versuchsfeld WFJ. Note again that WFJ is a point measurement and the other two are averages over areas. The difference in mean $\mathrm{HS}_{\text {tot }}$ between the rock face and the other two sites increased with higher $\mathrm{HS}_{\text {tot }}$ during the accumulation period. During the ablation period, no clear trend was found: the difference to Albertibach decreased, while the difference to the WFJ first increased until the end of April, but finally also decreased towards the end of May.

Regarding changes of $\mathrm{HS}_{\text {tot }}$ during periods with snowfall, more snow accumulated in the more gently sloping sites than

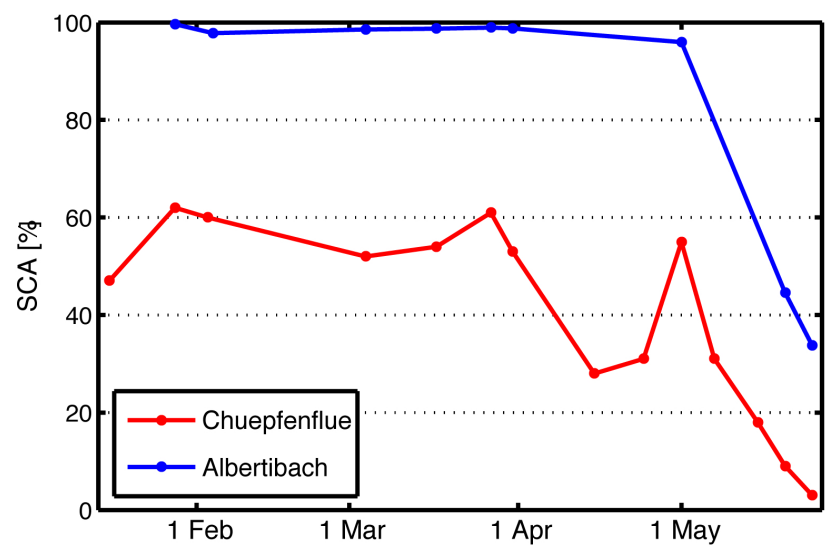

Fig. 4. Snow covered area (SCA) in the rock face Chüpfenflue and in the Albertibach catchment from 16 January to 25 May 2009. SCA was calculated for the entire base area.

in the rock face, except during the first observation period when snowfall was accompanied by weak wind (Table 2). The highest difference occurred in the last period of the accumulation season: while at Albertibach an increase in $\mathrm{HS}_{\text {tot }}$ of $41 \mathrm{~cm}$ and at WFJ of $31 \mathrm{~cm}$ was measured, $\mathrm{HS}_{\text {tot }}$ at Chüpfenflue increased only by $13 \mathrm{~cm}$. During the Föhn period in February, the reduction of $\mathrm{HS}_{\text {tot }}$ in the rock face was comparably higher. During the the first part of the ablation season the reduction of $\mathrm{HS}_{\text {tot }}$ was mostly higher at the flatter sites, but towards the end of the accumulation season the reduction was greater in the rock face.

Throughout the observation period, SCA in the rock face was at least $10 \%$ lower than at Albertibach (Fig. 4). During the accumulation period in the rock face, at least $20 \%$ of the area remained snow free, at Albertibach maximal 3\%. The highest relative difference in SCA (33\%) between the two sites occurred in the middle of May, when already most of the area in the rock face was snow free $(\mathrm{SCA}=11 \%)$.

The spatial variability of $\mathrm{HS}_{\text {tot }}$ at Chüpfenflue $(1.98<\mathrm{CV}<4.5)$ was at least $30 \%$ higher than at $\mathrm{Al}$ bertibach $(0.53<\mathrm{CV}<2.5)$ throughout the entire observation period. During the accumulation season the difference was smaller $\left(\max \mathrm{CV}_{\text {diff }}=0.5\right.$ ) than during the ablation period $\left(\max \mathrm{CV}_{\text {diff }}=2.9\right)$. In addition, the changes in $\mathrm{HS}_{\text {tot }}$ were more variable in the rock face than in the Albertibach catchment, except during the first two periods with snowfall in combination with practically no wind, or with a Föhn event (Table 2).

\subsection{Snow depth distribution in the rock face}

The spatial patterns of HS in the rock face remained similar during the entire winter (Fig. 5). The main snow accumulations occurred in the lee of ridges orientated normal to the prevailing wind direction (northwest), in small gullies, or at the foot of steep rocks. Fig. 6 points out that 

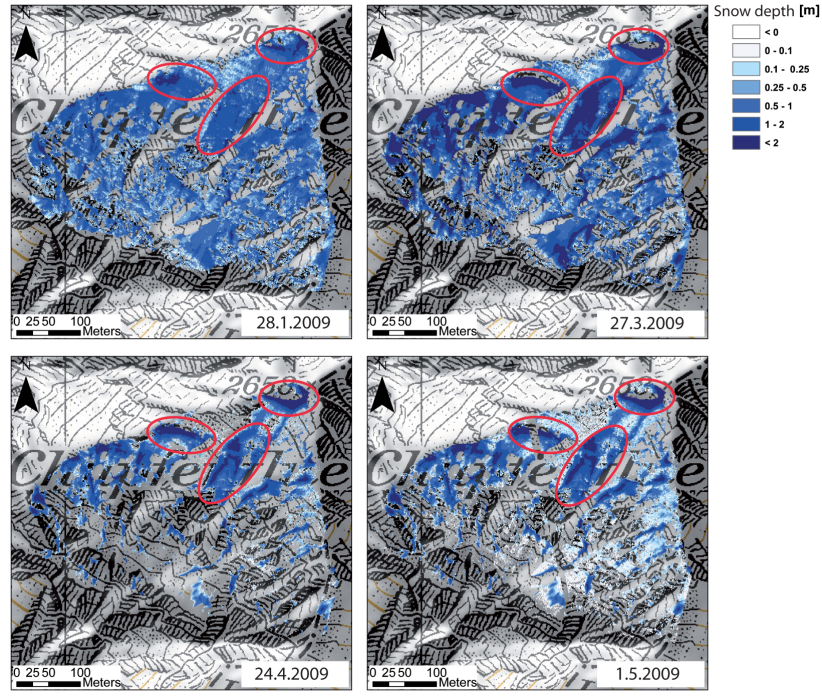

Fig. 5. Snow depth (HS) in the rock face Chüpfenflue in winter 2009. The red circles show areas with high HS during the entire winter.

cells with the highest $5 \%$ of HS were always found to be at the same locations for the different measurement times. Cells with only a thin snow cover mostly occurred on ridges or around the peak. Those repeating patterns were also expressed in high correlations between the HS distributions of different measurement dates (Table 4) and especially with the patterns of $\mathrm{HS}_{\max }$, the $\mathrm{HS}$ at the end of the accumulation season $(R>0.79)$ between the two winters studied. The correlations between HS after the first snowfall in winter 2009/2010 to $\mathrm{HS}_{\max }$ of the winter 2008/2009 were weaker $(0.37<R<0.47)$.

Even if the spatial patterns of HS were similar during the entire observation period, the distribution of HS changes during one single observation period varied, depending on weather conditions (e.g. snowfall in combination with strong north westerly winds vs. snowfall with weak winds). During the accumulation season, periods with snowfall accompanied by strong winds were most frequent (Table 3). The patterns of HS changes during those periods were similar (Fig. 7 and Table 5) and correlated well with the spatial distribution of $\mathrm{HS}_{\max }$ (Table 5). During a period with snowfall and weak winds (16 to 28 January) the distribution of HS changes showed a more homogeneous pattern and lower variability $(\mathrm{CV}=0.62$, Table 3$)$. In comparison with periods with strong winds $\left(\mathrm{CV}_{\min }=1.22\right)$, snow accumulated more regularly, no particular accumulation zones were established and areas, which normally stayed snow free during snowfalls, became snow covered (highest SCA on 28 January, Fig. 4). The distribution of HS after the snowfall event with no wind did not correlate well with $\mathrm{HS}_{\max }(R=0.18)$ or HS change $\left(|R|_{\max }=0.17\right)$; but it correlated negatively to the HS changes (ablation) in February due to a Föhn event $(R=-0.55)$.

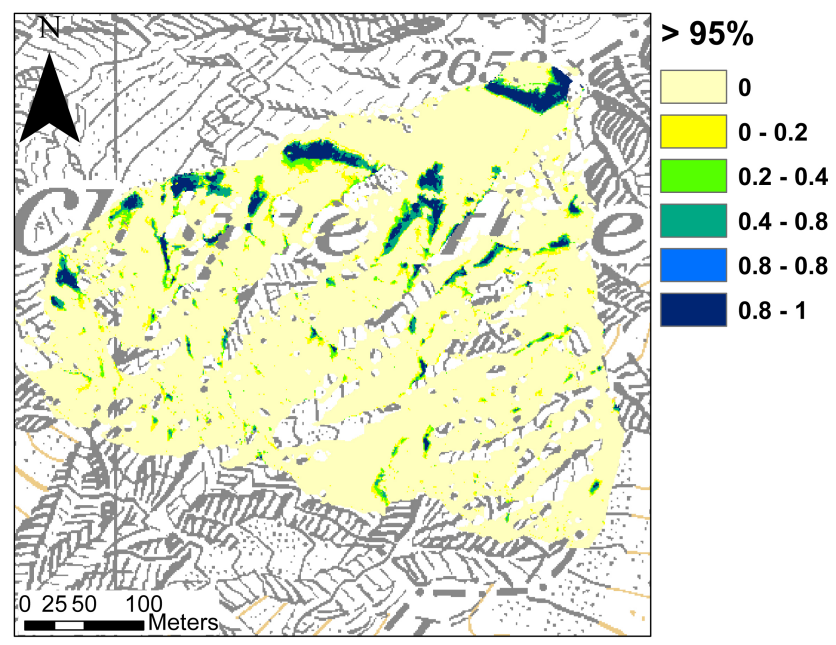

Fig. 6. Frequency of cells with highest HS per observation day over the winter 2008/2009. The frequency shows how often a cell had a HS within the range of HS of $5 \%$ of the cells with the highest HS of this observation day (calculated based on a cumulative histogram of HS per observation day). A value of one means that a cell had on all observation days a HS within the range of HS of the $5 \%$ of cells with the highest HS of this observation day.
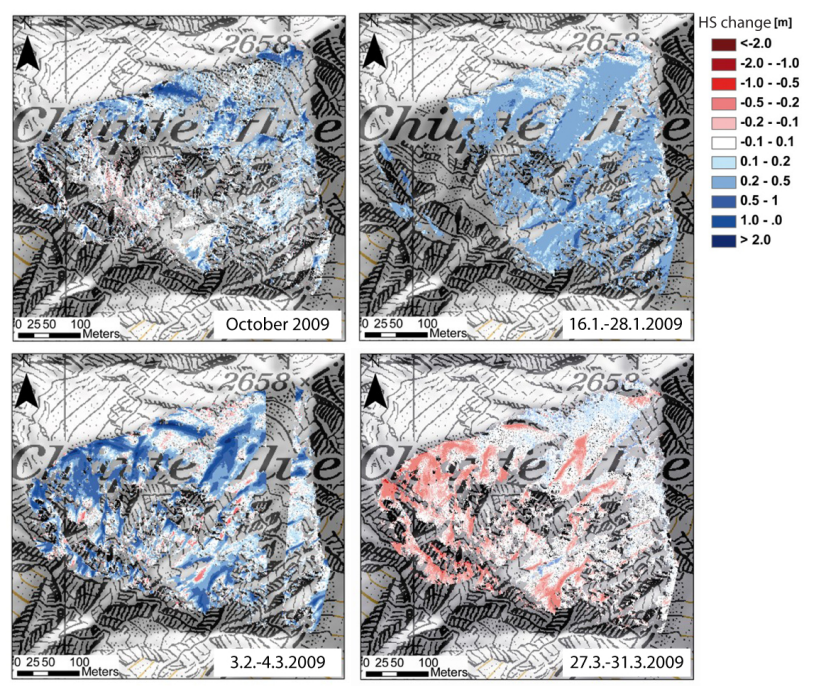

Fig. 7. Snow depth changes (dHS) during different observation periods in the rock face Chüpfenflue during the winter 2009 and of the first snowfall events of the winter 2009/2010 in October 2009.

During the ablation season the patterns of changes in HS were mainly influenced by the distribution of the persisting snow depth. Where $\mathrm{HS}_{\max }$ was high, its reduction was stronger (Figs. 5 and 7). These observations were confirmed by strong negative correlations of $\mathrm{HS}$ changes with $\mathrm{HS}_{\max }$ $(-0.55<R<-0.31$, Table 5) as well as by a KruskalWallis-test (Fig. 10). 
Table 4. Persons Correlation coefficients between snow depth (HS) distributions in the rock face Chüpfenflue on different days in 2009.

\begin{tabular}{|c|c|c|c|c|c|c|c|c|c|c|c|c|c|c|c|c|}
\hline Date & $16 \mathrm{Jan}$ & $28 \mathrm{Jan}$ & $2 \mathrm{Mar}$ & $4 \mathrm{Mar}$ & 17 Mar & 27 Mar & 31 Mar & ALS & $15 \mathrm{Apr}$ & $24 \mathrm{Apr}$ & 1 May & 7 May & 15 May & 20 May & 25 May & 21. Oct \\
\hline 16 Jan & 1 & 0.95 & 0.94 & 0.89 & 0.86 & 0.83 & 0.84 & 0.78 & 0.78 & 0.8 & 0.82 & 0.8 & 0.73 & 0.68 & 0.54 & 0.69 \\
\hline $28 \mathrm{Jan}$ & 0.95 & 1 & 0.95 & 0.9 & 0.87 & 0.82 & 0.83 & 0.67 & 0.75 & 0.76 & 0.77 & 0.75 & 0.68 & 0.61 & 0.47 & 0.58 \\
\hline 2 Mar & 0.94 & 0.95 & 1 & 0.88 & 0.84 & 0.79 & 0.79 & 0.59 & 0.72 & 0.74 & 0.75 & 0.73 & 0.7 & 0.62 & 0.5 & 0.55 \\
\hline 4 Mar & 0.89 & 0.9 & 0.88 & 1 & 0.97 & 0.95 & 0.95 & 0.65 & 0.9 & 0.88 & 0.86 & 0.88 & 0.82 & 0.78 & 0.77 & 0.53 \\
\hline $17 \mathrm{Mar}$ & 0.86 & 0.87 & 0.84 & 0.97 & 1 & 0.98 & 0.98 & 0.85 & 0.95 & 0.95 & 0.92 & 0.95 & 0.89 & 0.89 & 0.87 & 0.55 \\
\hline $27 \mathrm{Mar} \mathrm{HS}_{\max }$ & 0.83 & 0.82 & 0.79 & 0.95 & 0.98 & 1 & 0.99 & 0.72 & 0.93 & 0.92 & 0.89 & 0.91 & 0.83 & 0.81 & 0.8 & 0.47 \\
\hline 31 Mar & 0.84 & 0.83 & 0.79 & 0.95 & 0.98 & 0.99 & 1 & 0.74 & 0.95 & 0.94 & 0.91 & 0.93 & 0.86 & 0.85 & 0.83 & 0.47 \\
\hline ALS 9 Apr & 0.78 & 0.67 & 0.59 & 0.65 & 0.85 & 0.72 & 0.74 & 1 & 0.81 & 0.88 & 0.77 & 0.81 & 0.75 & 0.8 & 0.91 & 0.37 \\
\hline $15 \mathrm{Apr}$ & 0.78 & 0.75 & 0.72 & 0.9 & 0.95 & 0.93 & 0.95 & 0.81 & 1 & 0.98 & 0.97 & 0.97 & 0.9 & 0.88 & 0.87 & 0.52 \\
\hline $24 \mathrm{Apr}$ & 0.8 & 0.76 & 0.74 & 0.88 & 0.95 & 0.92 & 0.94 & 0.88 & 0.98 & 1 & 0.98 & 0.98 & 0.95 & 0.94 & 0.93 & 0.54 \\
\hline 1 May & 0.82 & 0.77 & 0.75 & 0.86 & 0.92 & 0.89 & 0.91 & 0.77 & 0.97 & 0.98 & 1 & 0.98 & 0.93 & 0.9 & 0.92 & 0.53 \\
\hline 7 May & 0.8 & 0.75 & 0.73 & 0.88 & 0.95 & 0.91 & 0.93 & 0.81 & 0.97 & 0.98 & 0.98 & 1 & 0.94 & 0.92 & 0.93 & 0.52 \\
\hline 15 May & 0.73 & 0.68 & 0.7 & 0.82 & 0.89 & 0.83 & 0.86 & 0.75 & 0.9 & 0.95 & 0.93 & 0.94 & 1 & 0.97 & 0.97 & 0.52 \\
\hline 20 May & 0.68 & 0.61 & 0.62 & 0.78 & 0.89 & 0.81 & 0.85 & 0.8 & 0.88 & 0.94 & 0.9 & 0.92 & 0.97 & 1 & 0.97 & 0.53 \\
\hline 25 May & 0.54 & 0.47 & 0.5 & 0.77 & 0.87 & 0.8 & 0.83 & 0.91 & 0.87 & 0.93 & 0.92 & 0.93 & 0.97 & 0.97 & 1 & 0.33 \\
\hline $21 \mathrm{Oct}$ & 69 & 0.58 & 0.55 & 0.53 & 0.55 & 0.47 & 0.47 & 0.37 & 0.52 & 0.54 & 0.53 & 0.52 & 0.52 & 0.53 & 0.33 & 1 \\
\hline
\end{tabular}

Table 5. Persons Correlation coefficients between distributions of snow depth change (dHS) and snow depth at the end of the accumulation season $\left(\mathrm{HS}_{\max }\right)$ in the rock face Chüpfenflue on different days in 2009. Periods are described in Table 3.

\begin{tabular}{|c|c|c|c|c|c|c|c|c|c|c|c|c|c|c|c|}
\hline Period & 1 & 2 & 3 & 4 & 5 & 6 & 7 & 8 & 9 & 10 & 11 & 12 & 13 & 0 & $\mathrm{HS}_{\max }$ \\
\hline 1 & 1 & -0.55 & 0.1 & 0.08 & 0.01 & -0.17 & -0.08 & -0.13 & -0.01 & -0.06 & -0.2 & 0.04 & 0.1 & -0.06 & 0.18 \\
\hline 2 & -0.55 & 1 & -0.28 & -0.2 & -0.14 & 0.03 & 0.17 & 0.05 & 0.05 & 0.06 & 0.31 & 0.09 & 0.04 & -0.03 & -0.22 \\
\hline 3 & 0.1 & -0.28 & 1 & 0.56 & 0.48 & -0.44 & -0.51 & -0.33 & -0.02 & -0.06 & -0.42 & -0.33 & -0.25 & 0.3 & 0.82 \\
\hline 4 & 0.08 & -0.2 & 0.56 & 1 & 0.45 & -0.47 & -0.48 & -0.33 & 0 & 0.04 & -0.33 & -0.31 & -0.24 & 0.28 & 0.74 \\
\hline 5 & 0.01 & -0.14 & 0.48 & 0.45 & 1 & -0.62 & -0.45 & -0.27 & -0.01 & 0.06 & -0.34 & -0.21 & -0.3 & 0.19 & 0.63 \\
\hline 6 & -0.17 & 0.03 & -0.44 & -0.47 & -0.62 & 1 & 0.38 & 0.33 & 0.04 & 0.06 & 0.4 & 0.18 & 0.17 & -0.07 & -0.43 \\
\hline 7 & -0.08 & 0.17 & -0.51 & -0.48 & -0.45 & 0.38 & 1 & 0.26 & 0.03 & 0.14 & 0.51 & 0.22 & 0.24 & -0.12 & -0.55 \\
\hline 8 & -0.13 & 0.05 & -0.33 & -0.33 & -0.27 & 0.33 & 0.26 & 1 & -0.28 & -0.01 & 0.34 & 0.12 & 0.2 & -0.01 & -0.31 \\
\hline 9 & -0.01 & 0.05 & -0.02 & 0 & -0.01 & 0.04 & 0.03 & -0.28 & 1 & -0.31 & -0.14 & -0.02 & 0.1 & 0.04 & 0.04 \\
\hline 10 & -0.06 & 0.06 & -0.06 & 0.04 & 0.06 & 0.06 & 0.14 & -0.01 & -0.31 & 1 & -0.17 & 0.09 & 0.08 & 0 & -0.06 \\
\hline 11 & -0.2 & 0.31 & -0.42 & -0.33 & -0.34 & 0.4 & 0.51 & 0.34 & -0.14 & -0.17 & 1 & 0.21 & 0.07 & -0.12 & -0.51 \\
\hline 12 & 0.04 & 0.09 & -0.33 & -0.31 & -0.21 & 0.18 & 0.22 & 0.12 & -0.02 & 0.09 & 0.21 & 1 & 0.17 & -0.23 & -0.47 \\
\hline 13 & 0.1 & 0.04 & -0.25 & -0.24 & -0.3 & 0.17 & 0.24 & 0.2 & 0.1 & 0.08 & 0.07 & 0.17 & 1 & -0.24 & -0.45 \\
\hline 0 & -0.06 & -0.03 & 0.3 & 0.28 & 0.19 & -0.07 & -0.12 & -0.01 & 0.04 & 0 & -0.12 & -0.23 & -0.24 & 1 & 0.47 \\
\hline $\mathrm{Hs}_{\max }$ & 0.18 & -0.22 & 0.82 & 0.74 & 0.63 & -0.43 & -0.55 & -0.31 & 0.04 & -0.06 & -0.51 & -0.47 & -0.45 & 0.47 & 1 \\
\hline
\end{tabular}

\subsection{Correlation with terrain features}

The correlation analysis between snow distributions and terrain parameters showed similar results for all cell sizes (Table 6). Only weak correlations between changes in HS or absolute HS and slope angle $\left(|R|_{\max }=0.13\right)$, curvature $\left(|R|_{\max }=0.21\right)$ and surface roughness $\left(|R|_{\max }=0.21\right)$ were found. Correlations were particularly small $\left(|R|_{\max }=0.09\right)$ during the ablation season. The results of a Kruskall-WallisTest support that slope has nearly no influence on the amount of negative HS changes (Fig. 10, topleft).

Even though correlations between terrain parameters and HS were weak, snow-covered cells at the end of the accumulation period differed significantly from the snow-free cells with regard to slope angle and surface roughness (Fig. 10). The snow-covered cells at the end of the accumulation season were significantly less steep and less rough. Note that steepness and roughness have been determined from the summer
DEM as described above. On the other hand, at the end of the accumulation period nearly $40 \%$ of the snow covered cells had slope angles between $35^{\circ}$ and $40^{\circ}$, but less than $5 \%$ of the snow covered cells had slope angles lower than $30^{\circ}$ (Fig. 8). The highest $\mathrm{HS}_{\max }$ in the rock face occurred in areas around $40^{\circ}$ and not in flat parts of the rock face as may have been expected. Cells with slope angles between $35^{\circ}$ and $40^{\circ}$ had an average $\mathrm{HS}_{\max }$ of $1.5 \mathrm{~m}$. The mean $\mathrm{HS}_{\max }$ of cells with a slope angle lower than $30^{\circ}$ was only around $1 \mathrm{~m}$, similar to the mean $\mathrm{HS}_{\max }$ of cells with a steepness between $60^{\circ}$ and $70^{\circ}$. Smallest variability of HS occurred around $35^{\circ}$ where mean HS was highest (Fig. 8). In areas with steep slopes the coefficient of variation of HS is much higher than in gently-sloping terrain. The distribution of slope angles in the rock face is not uniform and only few cells have slope angles below $30^{\circ}$ or higher than $70^{\circ}$ (Fig. 9, right axis).

The influence of slope angles on SCA was examined independently of their distribution (Fig. 9). The highest SCA 
Table 6. Persons Correlation coefficients between snow depth (HS) and HS change distributions of different periods (see Table 3), respectively on different days, and terrain parameters with different cellsizes.

\begin{tabular}{lrrrrr}
\hline Slope & $1 \mathrm{~m}$ & $2 \mathrm{~m}$ & $5 \mathrm{~m}$ & $10 \mathrm{~m}$ & $25 \mathrm{~m}$ \\
\hline Period 5 & -0.06 & -0.04 & -0.03 & -0.08 & -0.01 \\
Period 1 & 0.08 & 0.04 & 0.07 & 0.13 & 0.06 \\
Period 2 & -0.08 & -0.03 & -0.07 & -0.1 & -0.03 \\
Period 11 & 0 & 0.06 & 0 & 0.01 & 0.03 \\
Period 9 & -0.06 & -0.01 & -0.04 & -0.09 & 0 \\
HS 27 Mar 2009 & -0.08 & -0.1 & -0.06 & -0.09 & -0.06 \\
HS 25 May 2009 & 0.05 & -0.06 & 0 & -0.08 & -0.1 \\
HS 21 Oct 2009 & -0.09 & -0.05 & -0.06 & -0.12 & -0.02 \\
\hline CURVATURE & $1 \mathrm{~m}$ & $2 \mathrm{~m}$ & $5 \mathrm{~m}$ & $10 \mathrm{~m}$ & $25 \mathrm{~m}$ \\
\hline Period 5 & -0.09 & -0.09 & 0 & -0.15 & -0.03 \\
Period 1 & -0.14 & -0.18 & -0.01 & -0.21 & -0.13 \\
Period 2 & 0.03 & 0.12 & 0.02 & 0.14 & 0.1 \\
Period 11 & 0.2 & 0.09 & 0 & 0.14 & 0.08 \\
Period 9 & -0.06 & 0.01 & 0 & 0.05 & 0.03 \\
HS 27 Mar 2009 & -0.17 & -0.11 & 0 & -0.2 & -0.08 \\
HS 25 May 2009 & -0.06 & 0.11 & -0.02 & -0.07 & -0.03 \\
HS 21 Oct & -0.32 & -0.04 & -0.01 & -0.02 & 0.01 \\
\hline ROUGHNESS & $1 \mathrm{~m}$ & $2 \mathrm{~m}$ & $5 \mathrm{~m}$ & $10 \mathrm{~m}$ & $25 \mathrm{~m}$ \\
\hline Period 5 & -0.13 & -0.12 & -0.05 & -0.02 & 0.01 \\
Period 1 & 0.1 & 0.13 & 0.17 & 0.14 & -0.11 \\
Period 2 & -0.06 & -0.08 & -0.1 & -0.08 & 0.01 \\
Period 11 & 0.07 & 0.04 & -0.02 & -0.01 & -0.01 \\
Period 9 & -0.04 & -0.05 & -0.05 & 0 & -0.02 \\
HS 27 Mar 2009 & -0.13 & -0.11 & -0.03 & 0.01 & 0 \\
HS 25 May 2009 & -0.03 & -0.11 & -0.1 & -0.12 & 0.21 \\
HS 21 Oct 2009 & -0.11 & -0.11 & -0.11 & -0.07 & -0.02 \\
\hline & & & & &
\end{tabular}

occurred around $40^{\circ}$, where HS was largest (Fig. 8). Nevertheless, $70 \%$ of the cells with slope angles between $50^{\circ}$ and $55^{\circ}$ and $50 \%$ of those with slope angles between $60^{\circ}$ and $65^{\circ}$ were snow covered. However, in classes with slope angles lower than $30^{\circ}$ up to $50 \%$ of the cells remained snow free. Most of the near-horizontal areas in the rock face occur on wind-exposed ridges or close to the summit, where airflow often accelerates. This may explain the high proportion of gently-sloping snow free cells. However, this might not be the case in rock faces were flat areas are less wind exposed.

To confirm the hypothesis that snowfall events with weak wind lead to higher SCA than those with a strong northwestwind, snowfalls with differing wind conditions were investigated. SCA was higher after snowfalls in calm conditions than after those with strong wind, at least in areas with slope angles between $20^{\circ}$ and $80^{\circ}$ (Fig. 9). The two curves differ mostly between $45^{\circ}$ and $70^{\circ}$ and show that snowfalls in calm conditions resulted in accumulation in steeper and rougher areas.

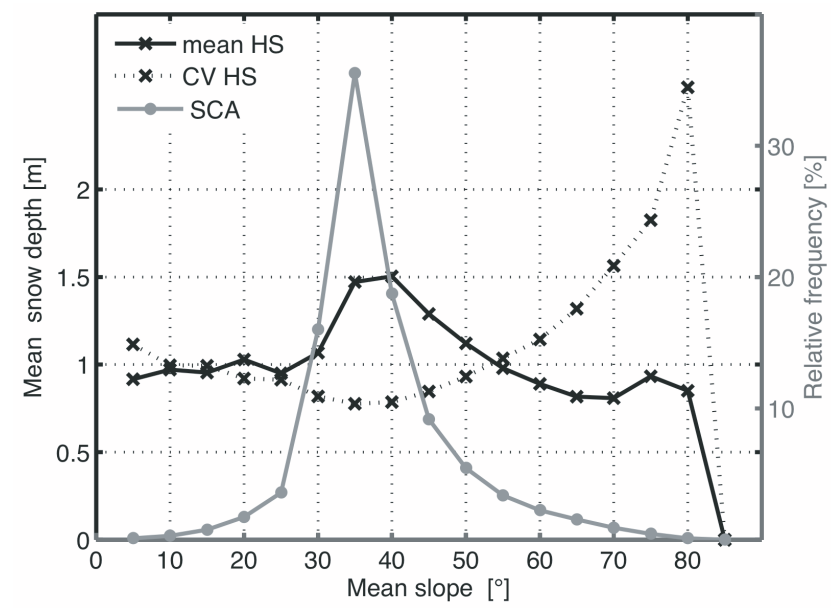

Fig. 8. Left axis: Histogram (calculated for classes with a step width of $5^{\circ}$ slope) of the mean snow depth (mean HS, left axis) and its coefficient of variation (CV HS). Right axis: Relative frequency of the snow covered cells (SCA) in the rock face Chüpfenflue on 27 March 2009.

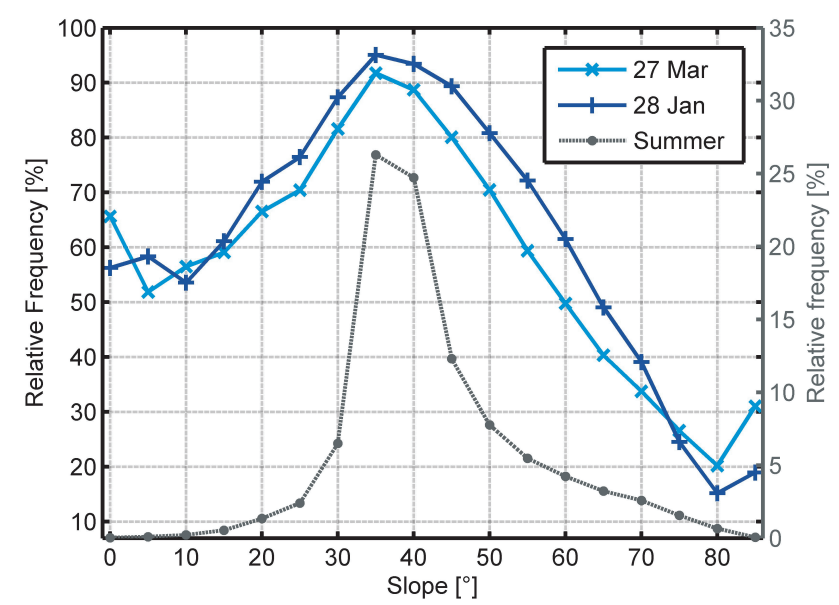

Fig. 9. The left axis shows the histogram with the relative frequencies of the snow covered cells per class (classes of cells with a step width of $5^{\circ}$ slope) after a period with snowfall in combination with weak winds (28 January), respectively in combination with strong northwest winds (27 March). The right axis shows the histogram of the slope angle distribution in summer (based on DEM $1 \mathrm{~m}$ ).

\section{Discussion}

\subsection{Applicability of TLS for HS measurements in steep and rough terrain}

To investigate the temporal and spatial variability of HS distributions in a rock face high temporal and spatial resolution is needed. The presented data include 14 measurement campaigns before or after an important snowfall or ablation 

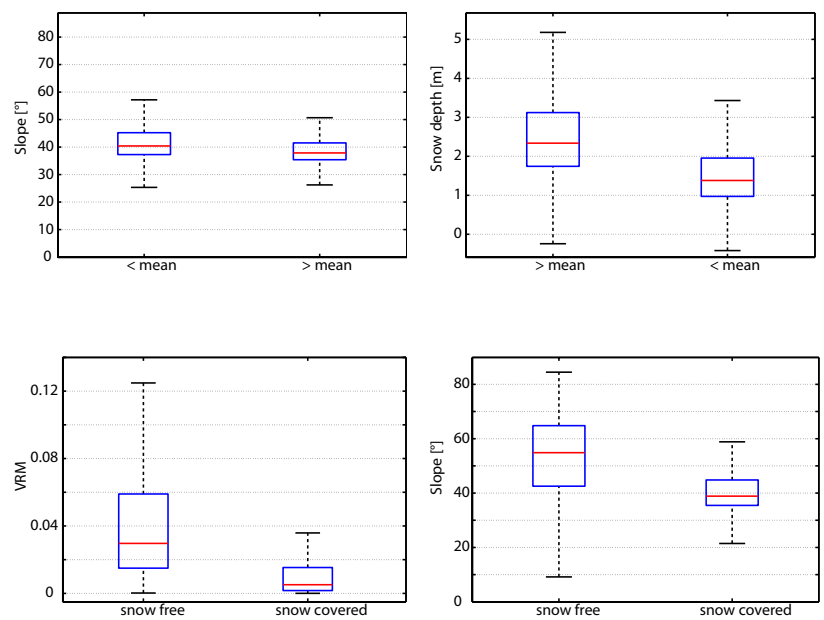

Fig. 10. Top: Box plots to compare slope angle (left plot) and snow depth at the end of the accumulation season ( $\mathrm{HS}_{\max }$, right plot) of cells with a snow depth change (dHS) higher (>mean) or lower ( $<$ mean) than the mean. dHS is given for period 7 , ranging from 31 March to 15 April 2009. Bottom: Box plots to compare surface roughness (VRM, left plot) and slope angle (right plot) of snow free or snow covered cells in the rock face Chüpfenflue. The snow cover is estimated based on the orthophoto from 27 March 2009 (end of the accumulation season).

event from January to May of the winter 2008/2009 and one additional scan after the first snowfall event of the winter 2009/2010. This temporal resolution allowed investigating the temporal evolution of HS and their changes in the rock face during one winter season. However, fast changes in HS, e.g. negative HS changes during the first clear days after a snowfall event or avalanching during storms, could not be investigated. Higher temporal resolution of measurements would strongly increase the possibilities to further improve knowledge about influencing processes.

As HS changes off all the observation periods were in the order of a few decimetres (Table 2), the accuracy of obtained HS data should be in the order of $\mathrm{cm}-\mathrm{dm}$. The analysis of the spatial variability of HS in a rock face requires a spatial grid resolution of a few metres, depending on the roughness of the investigated surface. In order to investigate processes, HS data should cover most areas of the rock face (lack of measurement shadows). The TLS point clouds, which had a small noise component and a mean density of more than 6 points per square metre, allowed to obtain interpolated HS data with a grid resolution of $1 \mathrm{~m}$. DSM from TLS data covered $60 \%$ of the base area of the rock face. Main measurement shadows occurred at the bottom of the rock face. Analysis showed that within the measurement shadows of the TLS interpolation does not lead to satisfactory results. Unfortunately, in this study, no direct accuracy estimations, similar to Prokop et al. (2008), were possible due to the inaccessibility of the rock face. To estimate the errors of obtained TLS data, repeatability and reproducibility tests were preformed (Sect. 2.5). Absolute errors of those tests were in the order of one decimetre $(8-13 \mathrm{~cm})$. Compared to the results of previous studies in more gentle terrain (e.g. Prokop et al., 2008; Grünewald et al., 2010) and product information from the manufacturer of the TLS Riegl (Riegl, 2005), results of this study had higher errors. The mean differences between ALSand TLS- DEMs, obtained in the rock face, were nearly $0.5 \mathrm{~m}$ and mainly occurred in the steep and rough areas, where distinct look angles most come into effect.

Findings of this study show that in a rock face - due to the rough topography - the performance of TLS to obtain HS data is poorer than in more gentle terrain. Nevertheless with a mean error of approximately one decimetre (reproducibility tests), data were suitable to study the spatial variability of HS and HS changes in a rock face even on a small scale $(1 \mathrm{~m})$. The high differences between the TLSand ALS-DEMs demonstrate the importance of a favourable look-angle.

\subsection{Factors influencing the distribution of HS}

During the entire observation season, the spatial patterns of HS remained similar although HS changes between periods differed depending on weather conditions. Strong wind dominated snowfall events and led to accumulation patterns in those periods, which correlated strongly with HS distribution at the end of the accumulation season. The distribution of HS is therefore strongly controlled by snowfall in combination with strong winds. Schirmer et al. (2011) made similar observations during the accumulation period in winter 2008/2009 in the Albertibach catchment. The timing of melt out was mostly dominated by the characteristics of those accumulations (cf. Grünewald et al., 2010; Anderton et al., 2002 and Luce et al., 1998). Correlations between HS and its changes with terrain parameters were generally weak and the correlation coefficients between HS at the end of the accumulation season and terrain parameters were similar to those of previous studies in smoother terrain (e.g. Anderton et al., 2002 and Winstral et al., 2002). Correlations were weaker during ablation than during accumulation (cf. Blöschel and Kirnbauer, 1992). The hypothesis that rough terrain tends to accumulate more snow is not supported (Fig. 10) in agreement with the recent study of Lehning et al. (2011), who show that rougher terrain holds less snow and that a fractal roughness parameter offers a high explanatory power for snow depth distribution. The difference to earlier and also this study in their approach has been that terrain characteristics are looked at for small sub-areas and not on a pixel basis (Lehning et al., 2011). The second hypothesis that snow cannot permanently accumulate at slope angles greater than a threshold (e.g., $>60^{\circ}$ ) due to avalanching is not supported (Fig. 8). We indeed found half of the cells were snow-covered in steep parts $\left(>60^{\circ}\right)$ of the rock face. This may be a result of the particular surface geometry of this rock face. A general decrease of HS with 
increasing slope angle is not confirmed by our data, either (Fig. 8). However, SCA at the end of the accumulation season was markedly less steep $\left(\right.$ median $\left.=39^{\circ}\right)$ than the snow free area $\left(\right.$ median $=44^{\circ}$ ). The comparison with previous studies that found a decrease in SCA with increasing slope (e.g. Blöschl and Kirnbauer, 1992) is difficult because they used coarser DEMs in terrain that was generally smoother than that in this study.

It appears that terrain-wind interactions played a major role in the rock face because the main accumulation zones were in the lee behind ridges (Figs. 5 and 6), highest HS occurred in areas with a steepness between $30^{\circ}$ and $55^{\circ}$ (Fig. 8), comparably little snow was accumulated during periods with strong winds and flat areas were mostly snow free due to wind-drift.

\subsection{Reasons for reduced $\mathrm{HS}$ in the rock face}

Compared to the more gently sloping sites, the rock face is characterized by smaller mean $\mathrm{HS}_{\text {tot }}$ and SCA as well as a higher variability of $\mathrm{HS}_{\text {tot }}$ (Fig. 3, Table 2 and Fig. 4). A possible reason for smaller $\mathrm{HS}_{\text {tot }}$ is higher snow density. The transport of snow by avalanching (which was not observed) or wind usually increases its density. Other possible reasons for the reduced $\mathrm{HS}_{\text {tot }}$ could include higher solar radiation input due to the topography or lower albedo (snow free areas) or evacuation of mass by avalanching and wind drift, and are discussed below.

As in previous studies (e.g. Lapen and Martz, 1996; Essery and Pomeroy, 2004 and Grünewald et al., 2010) we observed that borders of snow patches became snow free earlier than their centre parts and that areas with patchy snow cover became snow-free earlier than those with continuous snow cover. The faster meltout could be caused by the thinner snow cover at the borders or by the smaller albedo of the snow free areas with an associated transport of sensible heat to the borders of the snow patches. Neumann and Marsh (1998) found that the transport of sensible heat (advection processes) increases with decreasing patch size and increasing wind speed. The southwest exposure of the measured rock face may additionally promote these effects. The quantification of the effective difference in the reduction of HS at the borders compared to the central parts of the patches was not possible due to the limitations of the temporal resolution of our measurements but has been addressed by Mott et al. (2011). If mean $\mathrm{HS}_{\text {tot }}$ in the rock face was compared to an area inside the Albertibach catchment with similar slope aspect and slope angles, but generally much gentler and smoother terrain, the mean $\mathrm{HS}_{\text {tot }}$ and SCA in the rock face were still smaller; and the difference was similar to that in the entire Albertibach catchment. In addition we observed that within the rock face cells with comparably higher decrease in HS did only slightly differ from those with low changes regarding slope angle (Fig. 9). The influence of varying topography and lower albedo on smaller $\mathrm{HS}_{\text {tot }}$ could therefore not be shown in our analysis. For an improved understanding of processes related to solar radiation additional measurements with higher temporal resolution in rock faces with a larger range of slope aspects would be necessary.

Mean $\mathrm{HS}_{\text {tot }}$ in the rock face including the foot of slope where avalanches deposits would accumulate, was compared to the mean $\mathrm{HS}_{\text {tot }}$ in the Albertibach catchment. $\mathrm{HS}_{\text {tot }}$ were calculated based on the ALS measurements of 9 April 2009. Excluding the slope foot the mean $\mathrm{HS}_{\text {tot }}$ in the rock face was $0.6 \mathrm{~m}(\sigma=1.48 \mathrm{~m})$. Including the slope foot the mean snow depth was $0.8 \mathrm{~m}(\sigma=1.38 \mathrm{~m})$. In comparison to the $\mathrm{HS}_{\text {tot }}$ in the Albertibach catchment $(\mu=138 \mathrm{~cm}, \sigma=108 \mathrm{~cm})$ this was still almost $50 \%$ less. But a higher density of the deposited snow due to avalanching (e.g. Elder et al., 1998) could not have been considered because of the inaccessibility. It seems that avalanching contributed to causing a smaller $\mathrm{HS}_{\text {tot }}$ in the rock face but was not the main reason. Due to the fact that during periods with strong winds, e.g. from 18 to 27 March, comparably less snow was accumulated in the rock face than in the other two sites ( $70 \%$ less), while during a period with nearly no wind more snow accumulated in the rock face $(+10 \%$, period from 16 to 28 January, Table 2), we assume that wind transport may play a significant role. The observations suggest that total precipitation of snow per square meter horizontal surface is significantly reduced in the rock face compared to the neighbouring Albertibach. This supports the hypothesis that larger scale transport, which has been defined and described as preferential deposition by Lehning et al. (2008) and further described by Dadic et al. (2010) and Mott et al. (2010) accounted to a major part for the smaller $\mathrm{HS}_{\text {tot }}$ inside the rock face observed.

\section{Conclusions}

It was found that TLS is a suitable method for measuring snow-covered surfaces in steep and rough terrain. Based on the spatial resolution DSM with a grid size of $1 \mathrm{~m}$ could be obtained. The estimated errors were in the order of one decimetre and therefore suitable to analyze HS and HS changes of the observation periods.

Mean $\mathrm{HS}_{\text {tot }}$ and SCA in the rock face were lower during the entire winter compared to point measurements in a flat area and to TLS measurements in a smoother neighbouring catchment. The temporal evolution of mean $\mathrm{HS}_{\text {tot }}$ was similar at all three sites. Decreases in HS, especially during ablation periods, were generally stronger; increases generally smaller.

The distribution of HS in the rock face showed similar patterns during the entire observation period. Minima and maxima of HS always occurred in the same spots, even if distributions of HS change differed, depending on weather conditions. The main accumulation zones were in the lee behind ridges, orientated normal to the main wind direction. The distribution of $\mathrm{HS}_{\max }$ was mainly determined by snowfall in combination with strong northwest winds. Decreases of HS 
were stronger at places where HS was higher, yet these zones remained snow-covered the longest in spring.

Linear correlations between HS distributions and simple terrain parameters of the underlying topography were weak. Snow covered cells were generally smoother and less steep, but highest SCA and HS occurred at slopes with angles of approximately $40^{\circ}$ and not in the flattest parts of the rock face. On this small-scale we could not observe a decrease of HS or SCA with increasing slope angle and snow accumulated permanently even in very steep $\left(>50^{\circ}\right)$ terrain. More than $25 \%$ of the area, which was snow covered during the observed period in the accumulation season, was steeper than $50^{\circ}$. Terrain-wind interactions were likely the main factors influencing the variability of HS inside the rock face observed. In particular the total mass balance of the entire face compared to the Albertibach area suggests larger scale transport compatible with the idea of preferential deposition (Mott et al., 2010). Avalanching and slope-angle-dependent solar radiation played a minor role.

This study gives a first overview of HS in a rock face but it is a small rock face with a narrow range of slope aspects and altitude and only the HS development of one season was measured. We therefore expect that results may differ for other rock faces with different characteristics. To increase knowledge on processes contributing to the HS distribution in a rock face further measurements in rock faces with other characteristics as well as higher temporal resolution would help, as well as information about snow density. To describe the spatial HS distribution in a rock face the influence of wind-terrain-interactions should be investigated. Possibilities would be physically-based energywind-models (e.g. Mott et al., 2010) or parameterizations of wind-exposure such as the one formulated by Winstral et al. (2002).

Acknowledgements. This work was funded by the Swiss National Science Foundation and the Swiss Federal Office of the Environment. This study would not have been possible to carry out without the help in the field provided by Luca Egli, Yvonne Schaub, Thomas Grünewald, Rebecca Mott and other colleagues at SLF. Special thanks are dedicated to Thomas Grünewald, Lorenz Böckli and Andreas Hasler for fruitful discussions and valuable comments. In addition, we would like to thank Marcia Phillips, who polished the English.

Edited by: S. Dery

\section{References}

Alba, M., Longoni, L., Papini, M., Roncoroni, F., and Scaioni, M.: Feasibility and problems of TLS in modeling rock faces for hazard mapping, International Society for Photogrammetry and Remote Sensing, WG III/3 Workshop "Laser scanning 2005”, Enschede, the Netherlands, September 12-14, 2005.

Anderton, S., Withe, S., and Alvera, B.: Micro-scale spatial variability and the timing of snow melt runoff in a high mountain catchment, J. Hydrol., 268, 158-176, 2002.
Bauer, A., Paar, G., and Kaltenboeck, A.: Mass movement monitoring using terrestrial laser scanner for rock fall management, in: Geo-information for Disaster Management, edited by: van Oosterom, P., Zlatanova, S., and Fendel, E., Springer, Berlin, 393-406, 2005.

Blöschl, G. and Kirnbauer, R.: An analysis of snow cover patterns in a small alpine catchment, Hydrol. Process., 6, 99-109, 1992.

Cline, D., Bales, R., and Dozier, J.: Estimating the spatial distribution of snow in mountain basins using remote sensing and energy balance modeling, Water Resour. Res., 34, 1275-1285, 1998.

Dadic, R., Mott, R., Lehning, M., and Burlando, P.: Wind Influence on Snow Depth Distribution and Accumulation over Glaciers, J. Geophys. Res., 115, F01012, doi:10.1029/2009JF001261, 2010.

Deems, J., Fassnacht, S., and Elder, K.: Fractal distribution of snow depth from LiDAR data, J. Hydrometeorol., 7, 285-297, 2006.

Delaunay, B.: Sur la sphère vide, in: Bulletin of Academy of Sciences of the USSR 7, 793-800, 1934.

Doorschot, J., Raderschall, N., and Lehning, M.: Measurements and one-dimensional model calculations of snow transport over a mountain ridge, Ann. Glac., 32, 153-158, 2001.

Egli, L., Jonas, T., and Grünewald, T., Schirmer, M., and Burlando, P.: Dynamics of snow ablation in a small Alpine catchment observed by repeated terrestrial laser scans, Hydrol. Process., doi:10.1002/hyp.8244, accepted, 2011.

Elder, K., Dozier, J., and Michaelsen, J.: Snow accumulation and distribution in an alpine watershed, Water Resour. Res., 27, 1541-52, 1991.

Elder, K., Rosenthal, W., and Davis, R. E.: Estimating the spatial distribution of snow water equivalence in a montane watershed, Hydrol. Process., 12, 1793-1808, 1998.

Essery, R. and Pomeroy, J.: Implications of spatial distributions of snow mass and melt rate for snow-cover depletion: theoretical considerations, Ann. Glaciol., 38, 261-265, 2004.

Fierz, C., Armstrong, R. L., Durand, Y., Etchevers, P., Greene, E., McClung, D. M., Nishimura, K., Satyawali, P. K., and Sokratov, S. A.: The International Classification for Seasonal Snow on the Ground, IHP-VII Technical Documents in Hydrology $\mathrm{N}^{\circ} 83$, IACS Contribution $\mathrm{N}^{\circ} 1$, UNESCO-IHP, Paris, 2009.

Föhn, P. and Meister, R.: Distribution of snow drifts on ridge slope: measurements and theoretical approximations, Ann. Glac., 4, 52-57, 1983.

Gauer, P.: Numerical modeling of blowing and drifting snow in Alpine terrain, J. Glaciol., 47, 97-110, 2001.

Golding, D.: The correlation of snowpack with topography and snowmelt runoff on Marmot Creek Basin, Alberta. Atmosphere, 12, 31-38, 1974.

Gruber, S. and Haeberli, W.: Permafrost in steep bedrock slopes and its temperature-related destabilization following climate change, J. Geophys. Res., 112, F02S18, doi:10.1029/2006JF000547, 2007.

Grünewald, T., Schirmer, M., Mott, R., and Lehning, M.: Spatial and temporal variability of snow depth and ablation rates in a small mountain catchment, The Cryosphere, 4, 215-225, doi:10.5194/tc-4-215-2010, 2010.

Haeberli, W.: Die Permafrost-Faustregeln der VAW/ETHZ einige grundsätzliche Bemerkungen. Simulation der Permafrostverbreitung in den Alpen mit geographischen Informationssystemen, in: Arbeitsbericht NFP31, vdf-Hochschulverlag, 13-18, 1996.

Hasler, A., Gruber, S., and Haeberli, W.: Temperature variabil- 
ity and thermal offset in steep alpine rock and ice faces, The Cryosphere Discuss., 5, 721-753, doi:10.5194/tcd-5-721-2011, 2011.

Hopkinson, C., Sitar, M., Chamser, L., and Treit, P.: Mapping snowpack depth beneath forest canopies using airborne lidar, Photogrammetric engeneering and remote sensing, 70, 323-330, 2004.

Jörg, P., Fromm, R., Sailer, R., and Schaffhauser, A.: Measuring snow depth with a terrestrial laser ranging system, Proceedings for International Snow Science Workshop (ISSW), Telluride, USA, 452-460, 2006.

Keller, F. and Gubler, H.: Interaction between snow cover and high mountain permafrost: Murtèl/Corvatsch, Swiss Alps, in: Proceedings of the Sixth International Conference on Permafrost, 332-337, 1993.

Kenner, R., Phillips, M., Danioth, C., Denier, C., Thee, P., and Zgraggen, A.: Investigation of rock and ice loss in a recently deglaciated mountain rock wall using terrestrial laser scanning: Gemsstock, Swiss Alps, Cold Reg. Sci. Technol., 67, 157-164, doi:10.1016/j.coldregions.2011.04.006, 2011.

Lapen, D. and Martz, L.: An integrated system of the spatial association between snow depth and topography in a prairie agricultural landscape using digital terrain analysis, J. Hydrol., 184, 277-298, 1996.

Lehning, M., Löwe, H., Ryser, M., and Raderschall, N.: Inhomogeneous precipitation distribution and snow transport in steep terrain, Water Resour. Res., 44, W07404, doi:10.1029/2007WR006545, 2008.

Lehning, M., Grünewald, T., and Schirmer, M.: Mountain snow distribution governed by elevation and terrain roughness, Geophys. Res. Lett., 38, L19504, doi:10.1029/2011GL048927, 2011.

Liston, G. and Sturm, M.: A snow-transport model for complex terrain, J. Glaciol., 44, 498-516, 1998.

Lütschg, M., Lehning, M., and Haeberli, W.: A sensitivity study of factors influencing warm/thin permafrost in the Swiss Alps, J. Glaciol., 54, 696-704, 2008.

Luce, C., Tarboton, D., and Cooley, K.: The influence of the spatial distribution of snow on basin-averaged snowmelt, Hydrol. Proc., 12, 1671-1683, 1998.

Machguth, H., Paul, F., Hoelzle, M., and Haeberli, W.: Distributed glacier mass-balance modelling as an important component of modern multi-level glacier monitoring, Ann. Glac. 43, 335-343, 2006.

Mott, R. and Lehning, M.: Meteorological modelling of very high resolution wind fields and snow deposition for mountains, J. Hydromet., 11, 934-949, doi:10.1175/2010JHM1216.1, 2010.

Mott, R., Schirmer, M., Bavay, M., Grünewald, T., and Lehning, M.: Understanding snow-transport processes shaping the mountain snow-cover, The Cryosphere, 4, 545-559, doi:10.5194/tc-4-5452010, 2010.

Mott, R., Egli, E., Grünewald, T., Dawes, N., Manes, C., Bavay, M., and Lehning, M.: Micrometeorological processes driving snow ablation in an Alpine catchment, The Cryosphere Discuss., 5, 2159-2196, doi:10.5194/tcd-5-2159-2011, 2011.

Neumann, N. and Marsh, P.: Local advection of sensible heat in the snowmelt landscape of Arctic tundra, Hydrol. Proc., 12, 1547-1560, doi:10.1002/(SICI)10991085(199808/09)12:10/11;1547::AID-HYP680 ¿3.0.CO;2-Z, 1998.
Painter, H. and Dozier, J.: The effect of anisotropic reflectance on imaging spectroscopy of snow properties, Remote Sens. Environ., 89, 409-422, 2004.

Prokop, A.: Assessing the applicability of terrestrial laser scanning for spatial snow depth measurements, Cold Reg. Sci. Technol., 53, 155-163, 2008.

Prokop, A., Schirmer, M., Rub, M., Lehning, M., and Stocker, M.: A comparison of measurement methods: terrestrial laser scanning, tachymetry and snow probing, for the determination of the spatial snow depth distribution on slopes, Ann. Glaciol., 49, 210 216, 2008.

Raderschall, N., Lehning, M., and Schär, C.: Fine scale modelling of the boundary layer wind field over steep topography, Wat. Resour. Res., 44, W09425, doi:10.1029/2007WR006544, 2008.

Riegl: User manual of the Riegl Laser measurement systems and of the software package, 2005.

Sappington, M., Longshore, K., and Thompson, D.: Quantifying landscape ruggedness for animal habitant analysis: a case study using bighorn sheep in the Mojave Desert, J. Wildlife Manage., 71, 1419-1426, 2007.

Schaffhauser, A., Adams, M., Fromm, R., Jörg, P., Noferini, L., and Sailer, R.: Remote sensing based retrieval of snow cover proprieties, Cold Reg. Sci. Technol., 54, 165-175, 2008.

Schirmer, M., Wirz, V., Clifton, A., and Lehning, M.: Persistence in Intra-annual Snow Depth Distribution. Part I: Measurements and Topographic Control, Water Resour. Res., 47, W09516, doi:10.1029/2010WR009426, 2011.

Schmid, U. and Sardemann, S.: High frequency avalanches: release characteristics and run out distances, Cold Reg. Sci. Technol., 37 (3), ISSW 2002: International Snow Science Workshop, November 2003, 439-451, ISSN 0165-232X, doi:10.1016/S0165232X(03)00083-1, 2003.

Skaloud, J., Vallet, J., Keller, K., Veyssi'ere, G., and K”olbl, O.: An Eye for Landscapes - Rapid Aerial Mapping with Handheld Sensors, GPS World, 17, 26-32, 2006.

SLF: Schnee und Lawinen in den Schweizer Alpen Winter 2008/2009. Wetter Schnee und Lawinengefahr, WSL-Institut für Schnee- und Lawinenforschung, SLF. Jahresbericht des Winters 2008/2009, 2009.

Stoessel, F., Manes, C., Guala, M., Fierz, C., and Lehning, M.: On the micrometeorology of surface hoar on mountain snow covers, Water Resour. Res., 46, W04511, doi:10.1029/2009WR008198, 2010.

Trujillo, E., Ramirez, J., and Elder, K.: Topographic, meteorologic and canopy controls on the scaling characteristics of the spatial distribution of snow depth, Water Resour. Res., 43, W07409, doi:10.1029/2006WR005317, 2007.

Vallet, J. and Skaloud, J.: Helimap: Digital imagery/lidar handheld airborne mapping system for natural hazard monitoring, in: 6th Geomatic week, Barcelona, Spain, 2005.

Winstral, A., Elder, K., and Davis, R.: Spatial snow modelling of wind-redistributed snow using terrain-based parameters, J. Hydrometeorol., 3, 524-538, 2002.

Zenklusen, E., Blanchet, J., and Phillips, M.: Analysis of ground temperature trends in Alpine permafrost using generalized least squares, J. Geophys. Res. 115, F04009, doi:10.1029/2009JF001648, 12 pp., 2010. 